\title{
Assessment of different tomato genotypes for yield and morphological attributes
}

\author{
Muhammad Ismaee ${ }^{1 *}$, Muhammad Saleem Khan ${ }^{2}$, Syed Salim Shah ${ }^{2}$, \\ Zafar Ali ${ }^{1}$, Amjad Ali ${ }^{1}$, Saleha Tawab ${ }^{1}$ and Muhammad Naeem ${ }^{3}$ \\ 1. Agricultural Research Station Swabi, Department of Agricultural Research Khyber Pakhtunkhwa-Pakistan \\ 2. Department of Agriculture, Bacha Khan University of Charsadda-Pakistan \\ 3. Department of Agriculture, University of Swabi-Pakistan \\ *Corresponding author's email: ismaeelpbg@gmail.com \\ Citation \\ Muhammad Ismaeel, Muhammad Saleem Khan, Syed Salim Shah, Zafar Ali, Amjad Ali, Saleha Tawab and \\ Muhammad Naeem. Assessment of different tomato genotypes for yield and morphological attributes. Pure and \\ Applied Biology. Vol. 8, Issue 1, pp295-303. http://dx.doi.org/10.19045/bspab.2018.700188
}

\begin{tabular}{llll}
\hline \hline Received: 19/08/2018 & Revised: 02/11/2018 & Accepted: 10/11/2018 & Online First: 13/11/2018 \\
\hline
\end{tabular}

\section{Abstract}

This experiment was carried out to assess different tomato genotypes for yield and morphological attributes at Agricultural Research Station (ARS) Swabi during 2018. Experiment was laid out in a randomized complete block design (RCBD) with three replications. Results of the experiment showed significant differences among the tomato genotypes for all parameters except days to first flower initiation. Maximum number of flowers cluster $^{-1}$ (20.0 flowers) were observed for tomato genotype 006231 and maximum number of fruits inflorescence ${ }^{-1}$ (15.0) were recorded for genotypes 006231 and 00289, respectively. Maximum number of primary branches plant ${ }^{-1}$ (10.0 branches) and secondary branches plant ${ }^{-1}$ (24.0 branches) were developed by tomato genotype 017875. Bombino produced maximum fruit length (5.84 $\mathrm{cm})$ and fruit diameter $(4.99 \mathrm{~cm})$, respectively. Highest plant height was attained by genotype 017875 $(102.5 \mathrm{~cm})$ while Roma produced smaller plants $(49.9 \mathrm{~cm})$. Maximum numbers of fruit clusters plant ${ }^{-1}(28.0$ clusters) were produced by genotype 00289 whereas Red Wonder showed maximum fruit yield plot $^{-1}(3.74$ $\mathrm{kg}$ ). Higher values of phenotypic coefficient of variation (PCV) and genotypic coefficient of variation (GCV) were observed for number of secondary branches plant ${ }^{-1}$ (32.49\% and 31.69\%), number of fruit clusters plant ${ }^{-1}(29.03 \%$ and $25.94 \%)$, plant height (22.93\% and $\left.21.72 \%\right)$ and fruit yield plot $^{-1}$ (42.92\% and $39.63 \%)$. High broad sense heritability values were obtained for number of secondary branches plant ${ }^{-1}$ $(95.1 \%)$, fruit diameter $(66.8 \%)$, number of fruit clusters plant ${ }^{-1}(92.1 \%)$, plant height $(89.7 \%)$ and fruit yield plot $^{-1}(85.2 \%)$. On the basis of excellent performance for most of the yield and yield related parameters, the tomato genotypes Red Wonder, Bombino, 006231, 00289 and 017875 are recommended for onward use in tomato breeding programs for the development of commercial tomato varieties/hybrids. Keywords: Genetic variability; GCV; Heritability; PCV and Yield

\section{Introduction}

Tomato (Solanum lycopersicum L.) is one of the most important Solanaceous family vegetable crops grown widely all over the world. Tomatoes are believed to have originated in South America nonetheless they are now found round the globe. Being one of the world's largest grown vegetable crops, tomato occupies an important place in the economy of the world. Based on consumption of various vegetable crops, tomato ranks second after potato in the world [1]. Worldwide China ranks first in terms of total area and production of tomato.

Although tomatoes are commonly consumed fresh, over $80 \%$ of tomato consumption 
comes from processed products such as tomato juice, paste, puree, ketchup and sauce [2]. Tomato is also an important vegetable crop of Pakistan. In Pakistan tomato is grown on an area of 62930 hectares with production of 599588 tons [3]. Both determinate and indeterminate tomato varieties are grown in Khyber Pakhtunkhwa but the later one gave more production per unit area. In Khyber Pakhtunkhwa, area and production of tomato is 13950 hectares and 113200 tons, respectively [3].

Availability of genetic variation among different desirable and vital traits is necessary for vegetable breeder in order to develop potential materials of tomato plants through breeding and selection [4]. Many genotypes of tomato with desirable characteristics are available currently for commercial as well as home gardeners [5]. Genotypes selection in tomato is based on grower's specific choices' i.e. fruit size, texture, color, fruit chemistry, yield, adaptability to greenhouse or field conditions, requirement of light/temperature and post-harvest life [6]. Genetic variation in tomato genotypes can be estimated by observing the phenotypes of the plants and measuring the morphological characters. Morphological mode of characterization of the diverse genotypes is robust, reliable and less costly.

The observable differences among genotypes in a population is termed as phenotypic variation which is the composition of genetic and environmental variances. However, genetic variation is the true heritable variation which is not influenced by the environmental effects. Phenotypic coefficient of variation (PCV) and genotypic coefficient of variation (GCV) measure the amount of variability present in a population and gave the valuable information about the variability of different traits. Square root of phenotypic variance to grand mean is termed as PCV whereas GCV can be defined as square root of genotypic variance to grand mean. PCV values when higher than the respective GCV values for a particular trait depicts that major portion of total phenotypic variance in constituted by the environmental variance [7]. Broad sense heritability is the ratio of total genetic variance to the phenotypic variance [8]. Low heritability of quantitative traits such as yield is a major limiting factor in increasing productivity of crops in most plant breeding programs. The present study was therefore designed to characterize different tomato genotypes and assess genetic variability for yield and morphological traits. It was also aimed to find out most promising tomato genotypes for future breeding programs.

\section{Materials and methods}

The present study was performed to assess diverse tomato genotypes for yield and yield related traits at Agricultural Research Station (ARS) Swabi during 2018. The experimental material comprised 15 tomato genotypes (6 accessions and 9 varieties) which were replicated thrice in a randomized complete block design (RCBD). The accessions were provided by the Institute of Agriculture Biotechnology and Genetic Resources (IABGR), National Agricultural Research Center (NARC), Islamabad while tomato varieties were collected from the local market of Peshawar and Swabi. Each genotype was planted in 3 rows with row length of $3 \mathrm{~m}$. Row - row and plant - plant distances of $75.0 \mathrm{~cm}$ and $45.0 \mathrm{~cm}$, respectively were kept. Cultural practices i.e. fertilizer application, weeding and control of biotic factors were carried out in all experimental plots. Tomato genotypes used in the study are listed in the (Table 1). Data were recorded on 11 quantitative traits at appropriate stage of growth of each genotype. The traits studied were days to first flower initiation, days to first fruit development, number of flowers inflorescence $^{-1}$, number of fruits inflorescence ${ }^{-1}$, number of primary branches plant $^{-1}$, number of secondary branches plant 
1, fruit length $(\mathrm{cm})$, fruit diameter $(\mathrm{cm})$, number of fruit clusters plant ${ }^{-1}$, plant height $(\mathrm{cm})$ and fruit yield $\left(\mathrm{kg} \mathrm{plot}^{-1}\right)$.

\section{Statistical analysis}

Mean values were subjected to analysis of variance technique (ANOVA) as outlined by
[9] through statistical software Statistix (version 8.1). Genotypic and phenotypic variances, genotypic and phenotypic coefficients of variability and broad sense heritability were determined using the formulas suggested by [10].

Table 1. Tomato genotypes used in the study at Agricultural Research Station Swabi during 2018

\begin{tabular}{|c|c|c|}
\hline S. No. & Tomato Genotypes & Source \\
\hline 1. & Red wonder & Local market \\
\hline 2. & Bombino & Local market \\
\hline 3. & Riogrande & Local market \\
\hline 4. & Roma & Local market \\
\hline 5. & Rio Figou & Local market \\
\hline 6. & Jambo & Local market \\
\hline 7. & Kalam & Local market \\
\hline 8. & NSF-VF & Local market \\
\hline 9. & Red Star & NARC, Islamabad \\
\hline 10. & 006234 & NARC, Islamabad \\
\hline 11. & 006231 & NARC, Islamabad \\
\hline 12. & 00289 & NARC, Islamabad \\
\hline 13. & 006232 & NARC, Islamabad \\
\hline 14. & 017875 & NARC, Islamabad \\
\hline 15. & 017872 & \\
\hline
\end{tabular}

\section{Results and discussion}

\section{Days to first flower initiation}

Non-significant $(p \leq 0.05)$ differences were observed among the tomato genotypes for days to first flower initiation (Table 2). Among the genotypes, days to first flower initiation varied between 70.0 to 72.0 days. Red Wonder took minimum days (70.0) to first flower initiation. Maximum days (72.0) to first flower initiation were observed for the tomato genotypes Jumbo, NSF-VF, Red Star, 00289, 006232 and 017872 (Table 3). Our results are similar with the findings of [11], who also reported non-significant differences for days to first flower initiation. Low PCV, GCV and heritability values of $1.32 \%$ and $0.58 \%$ and $19.3 \%$, respectively were observed for days to first flower initiation (Table 4). [12] Also reported similar results of low PCV (6.42\%) and GCV (5.90\%) values but, they observed high heritability $(84.42 \%)$ value for this trait.

\section{Days to first fruit development}

Highly significant $(p \leq 0.01)$ differences were observed among the tomato genotypes for days to first fruit development (Table 2). Among the genotypes, days to first fruit development varied between 78.0 to 84.0 days. Red Wonder took minimum days (78.0) to first fruit development followed by Riogrande (79.0) whereas genotypes Bambino, Roma, Red Star, 006231, 006232 and 017872 took 80.0 days to first fruit development. Maximum days to first fruit development (84.0) were observed for the genotypes Kalam and 017875 (Table 3). [13] Observed non-significant differences for days to first fruit development which are not in line with our results. Low PCV (2.31\%), GCV $(1.70 \%)$ and moderate heritability 
(54.3\%) values were observed among the tomato genotypes for days to first fruit development (Table 4). [14] Manifested

Table 2. Mean square values for different traits of 15 tomato genotypes

\begin{tabular}{|l|c|c|c|}
\hline \multicolumn{4}{|c|}{ Mean Squares } \\
\hline \multicolumn{1}{|c|}{ Parameters } & Replications & Genotypes & Error \\
\hline Days to first flower initiation & 8.26667 & 1.23810 & 0.71905 \\
\hline Days to first fruit development & 4.46667 & $7.24762^{* *}$ & 1.58571 \\
\hline Number of flowers cluster $^{-1}$ & 0.14156 & $4.36737^{* *}$ & 1.65846 \\
\hline Number of fruits inflorescence $^{-1}$ & 0.78422 & $4.61403^{* *}$ & 1.24494 \\
\hline Number of primary branches plant $^{-1}$ & 0.68645 & $6.747558^{* *}$ & 2.18799 \\
Number of secondary branches plant $^{-1}$ & 1.5702 & $73.9245^{* *}$ & 1.2478 \\
\hline Fruit length (cm) $^{\text {Fruit diameter(cm) }}$ & 0.44696 & $2.15655^{* *}$ & 0.74156 \\
\hline Number of fruit Clusters plant $^{-1}$ & 0.19283 & $0.74514^{* *}$ & 0.10555 \\
\hline Plant height (cm) $\left.^{\text {Fruit yield (kg plot }}{ }^{-1}\right)$ & 7.6880 & $90.3080^{* *}$ & 2.5037 \\
\hline Degree of freedom & 13.898 & $799.467^{* *}$ & 29.413 \\
\hline
\end{tabular}

Table 3. Mean values for days to first flower initiation, days to first fruit development, number of flowers cluster ${ }^{-1}$ and number of fruit inflorescence ${ }^{-1}$ of different tomato genotypes

\begin{tabular}{|c|c|c|c|c|}
\hline Genotypes & $\begin{array}{c}\text { Days to first } \\
\text { flower initiation }\end{array}$ & $\begin{array}{c}\text { Days to first fruit } \\
\text { development }\end{array}$ & $\begin{array}{c}\text { Number of } \\
\text { flowers cluster }\end{array}$ & $\begin{array}{c}\text { Number of fruits } \\
\text { inflorescence }^{-1}\end{array}$ \\
\hline Red wonder & 70.0 & 78.0 & 17.0 & 12.0 \\
\hline Bombino & 71.0 & 80.0 & 16.0 & 11.0 \\
\hline Riogrande & 71.0 & 79.0 & 17.0 & 11.0 \\
\hline Roma & 71.0 & 80.0 & 17.0 & 12.0 \\
\hline Rio figou & 71.0 & 81.0. & 17.0 & 13.0 \\
\hline Jumbo & 72.0 & 81.0 & 17.0 & 13.0 \\
\hline Kalam & 71.0 & 84.0 & 17.0 & 13.0 \\
\hline NSF-VF & 72.0 & 81.0 & 17.0 & 12.0 \\
\hline Red star & 72.0 & 80.0 & 17.0 & 14.0 \\
\hline 006234 & 71.0 & 82.0 & 18.0 & 14.0 \\
\hline 006231 & 71.0 & 80.0 & 20.0 & 15.0 \\
\hline 00289 & 72.0 & 82.0 & 19.0 & 13.0 \\
\hline 006232 & 72.0 & 80.0 & 19.0 & 14.0 \\
\hline 017875 & 71.0 & 84.0 & 18.0 & 13.0 \\
\hline 017872 & 72.0 & 80.0 & 18.0 & \\
\hline
\end{tabular}


Table 4. Phenotypic variance ( $\mathrm{Vp})$, genotypic variance $(\mathrm{Vg})$, phenotypic coefficient of variation (PCV), genotypic coefficient of variation (GCV), broad sense heritability $\left(\mathrm{h}^{2} \mathrm{bs}\right)$ and coefficient of variation $(\mathrm{CV})$ of 15 tomato genotypes

\begin{tabular}{|c|c|c|c|c|c|c|c|}
\hline Traits & $\mathbf{V p}$ & Vg & Ve & $\begin{array}{c}\text { PCV } \\
\%\end{array}$ & $\begin{array}{c}\text { GCV } \\
\%\end{array}$ & $\begin{array}{c}\mathbf{h}^{2}(\mathbf{b s} \\
) \%\end{array}$ & $\mathbf{C V}$ \\
\hline Days to first flower initiation & 0.89 & 0.17 & 0.71 & 1.32 & 0.58 & 19.3 & 2.00 \\
\hline Days to first fruit development & 3.47 & 1.88 & 1.58 & 2.31 & 1.70 & 54.3 & 1.56 \\
\hline Number of flowers cluster ${ }^{-1}$ & 2.56 & 0.90 & 1.56 & 9.11 & 5.41 & 35.3 & 7.33 \\
\hline Number of fruits inflorescence ${ }^{-1}$ & 2.36 & 1.12 & 1.24 & 11.95 & 8.23 & 47.3 & 8.67 \\
\hline Number of primary branches plant ${ }^{-1}$ & 3.70 & 1.51 & 1.18 & 24.69 & 15.80 & 40.9 & 18.6 \\
\hline Number of secondary branches plant ${ }^{-1}$ & 25.47 & 24.22 & 1.24 & 32.49 & 31.69 & 95.1 & 7.19 \\
\hline Fruit length $(\mathrm{cm})$ & 1.30 & 0.56 & 0.74 & 26.10 & 17.14 & 43.0 & 19.6 \\
\hline Fruit diameter $(\mathrm{cm})$ & 0.31 & 0.21 & 0.10 & 13.58 & 11.11 & 66.8 & 18.0 \\
\hline Number of fruit clusters plant $^{-1}$ & 31.77 & 29.26 & 2.50 & 29.03 & 25.94 & 92.1 & 7.59 \\
\hline Plant height $(\mathrm{cm})$ & 286.0 & 256.6 & 29.41 & 22.93 & 21.72 & 89.7 & 7.35 \\
\hline Fruit yield $\left(\mathrm{kg} \mathrm{plot}^{-1}\right)$ & 0.64 & 0.55 & 0.09 & 42.92 & 39.63 & 85.2 & 16.4 \\
\hline
\end{tabular}

\section{Number of flowers cluster-1}

Analysis of variance (ANOVA) showed highly significant $(\mathrm{p} \leq 0.01)$ differences among the tomato genotypes for number of flowers cluster ${ }^{-1}$ (Table 2). Mean data among the genotypes for number of flowers cluster ${ }^{-1}$ varied between 16.0 to 20.0. Maximum number of flowers cluster $^{-1}(20.0)$ were developed by 006231 while 006232 and 00289 produced 19.0 flowers cluster $^{-1}$, respectively. Minimum numbers of flowers cluster $^{-1}$ (16.0) were observed for the genotype Bombino (Table 3). [15] Also reported highly significant differences for number of flowers cluster $^{-1}$ which are according to our results. Tomato genotypes displayed low PCV and GCV values of $9.11 \%$ and $5.41 \%$, respectively while moderate heritability value of $35.3 \%$ for number of flowers cluster ${ }^{-1}$ (Table 4). [16] Also reported similar results of low PCV $(1.20 \%)$ and $\mathrm{GCV}(0.96 \%)$ values but they recorded high heritability $(80.80 \%)$ for number of flowers cluster ${ }^{-1}$.

\section{Number of fruits inflorescence ${ }^{-1}$}

Mean square data for number of fruits inflorescence ${ }^{-1}$ showed highly significant $(\mathrm{p} \leq$ 0.01 ) differences among tomato genotypes
(Table 2). Mean values among tomato genotypes, for number of fruits inflorescence ${ }^{1}$ ranged from 11.0 to 15.0 . Riogrande and Bambino developed minimum number of fruits inflorescence ${ }^{-1}(11.0)$ while maximum number of fruits inflorescence ${ }^{-1}$ (15.0) were observed for the tomato genotypes 006231 and 00289. Red Star, 006234 and 017875 showed 14.0 number of fruits inflorescence ${ }^{-1}$ (Table 3). The findings of this study are in line with the results of [15]. Moderate PCV $(11.95 \%)$, low GCV $(8.23 \%)$ and moderate heritability $(47.3 \%)$ values were observed among the tomato genotypes for number of fruits inflorescence ${ }^{-1}$ (Table 4). [6] reported low PCV $(0.24 \%)$ and GCV $(0.22 \%)$ values whereas high heritability $(91.90 \%)$ value in his study for number of fruits inflorescence ${ }^{-1}$. Number of primary branches plant ${ }^{-1}$ Highly significant $(\mathrm{p} \leq 0.01)$ differences were observed among the tomato genotypes for number of primary branches plant ${ }^{-1}$ (Table 2). Among the genotypes, number of primary branches plant ${ }^{-1}$ varied between 6.0 to 10.0 branches. Minimum number of primary branches plant $^{-1}$ (6.0) were observed for tomato genotypes Roma, Rio Figou and Kalam. Tomato genotypes 00289, 006232, 
017875 and 017872 exhibited maximum number of primary branches plant ${ }^{-1}(10.0)$ (Table 5). The findings of [17] are in line with our results who also observed highly significant differences for number of primary branches plant ${ }^{-1}$. Among the tomato genotypes, high PCV (24.69\%), moderate GCV $(15.80 \%)$ and moderate heritability $(40.9 \%)$ values were recorded for number of primary branches plant ${ }^{-1}$ (Table 4). [18] Observed high PCV (543.48\%), GCV $(521.24 \%)$ and high heritability $(95.91 \%)$ values for number of primary branches plant ${ }^{-}$ 1 .

\section{Number of secondary branches plant ${ }^{-1}$}

Mean square values showed highly significant $(\mathrm{p} \leq 0.01)$ differences among the tomato genotypes for number of secondary branches plant ${ }^{-1}$ (Table 2). Secondary branches among the tomato genotypes varied between 8.0 to 24.0 branches plant $^{-1}$. Tomato genotype Roma developed minimum number of secondary branches plant ${ }^{-1}$ (8.0) while maximum number of secondary branches plant $^{-1}$ (24.0) were observed for tomato genotype 017875 followed by 006231 (23.0) whereas 006234 and 00289 manifested 20.0 number of secondary branches plant ${ }^{-1}$ (Table 5). [17] Manifested similar results and showed highly significant differences for number of secondary branches plant ${ }^{-1}$. For number of secondary branches plant ${ }^{-1}$, high PCV, GCV and heritability values $32.49 \%$, $31.69 \%$ and $95.1 \%$, respectively were observed among the tomato genotypes (Table 4). [19] Manifested high heritability (99.65\%) but moderate PCV (18.59\%) and GCV $(18.55 \%)$ values for this trait.

\section{Fruit length (cm)}

Highly significant $(p \leq 0.01)$ differences were observed among the tomato genotypes for fruit length (Table 2). Among the tomato genotypes, fruit length varied between 3.23 to $5.84 \mathrm{~cm}$. Minimum fruit length $(3.23 \mathrm{~cm})$ was observed for tomato genotype 006234 . Tomato genotype Bombino manifested maximum fruit length $(5.84 \mathrm{~cm})$ followed by Roma and Red Wonder with values of 5.24 and $5.18 \mathrm{~cm}$, respectively (Table 5). [20] Manifested similar results and showed significant differences for fruit length. High PCV (26.10\%), moderate GCV (17.14\%) and heritability $(43.0 \%)$ values were recorded for fruit length (Table 4). [21] Displayed moderate PCV (12.05\%) and GCV (11.32\%) values and high heritability $(88.35 \%)$ for fruit length.

\section{Fruit diameter $(\mathrm{cm})$}

For fruit diameter, analysis of variance (ANOVA) showed highly significant $(p \leq 0.01)$ differences among the genotypes (Table 2). Table 4 shows mean fruit diameter ranging from 3.33 to $4.99 \mathrm{~cm}$. Minimum fruit diameter $(3.33 \mathrm{~cm})$ was recorded for tomato genotype 006234 while maximum fruit diameter $(4.99 \mathrm{~cm})$ was observed for Bombino followed by Red Wonder, Red Star and Riogrande with values of 4.77, 4.64 and $4.63 \mathrm{~cm}$, respectively (Table 5) Our results are in line with the findings of [20] who also observed significant differences for fruit diameter. Moderate PCV (13.58\%), GCV $(11.11 \%)$ and high heritability $(66.8 \%)$ were recorded in this study for fruit diameter (Table 4). [21] Reported moderate PCV (14.59\%), GCV (11.35\%) and heritability $(60.48 \%)$ for fruit diameter.

\section{Number of fruit clusters plant ${ }^{-1}$}

Highly significant $(\mathrm{p}<0.01)$ differences were observed among the tomato genotypes for number of fruit clusters plant ${ }^{-1}$ (Table 2). Among the tomato genotypes, number of fruit clusters plant ${ }^{-1}$ varied between 12.0 to 28.0 clusters. NSF-VF exhibited minimum number of fruit clusters plant ${ }^{-1}$ (12.0) whereas tomato genotype 00289 displayed maximum number of fruit clusters plant $^{-1}$ (28.0) followed by Kalam and 006231 both having 27.0 fruit clusters plant ${ }^{-1}$ (Table 6). [17] also observed highly significant differences for the number of fruit clusters plant $^{-1}$ which are according to our results. For 
number of fruit clusters plant ${ }^{-1}$ high PCV (29.03\%), GCV (25.94\%) and heritability $(92.1 \%)$ values were observed among the tomato genotypes (Table 4). [19] Observed similar results and showed high PCV, GCV and heritability values of $30.83 \%, 3.41 \%$ and $97.28 \%$, respectively for number of fruit clusters plant ${ }^{-1}$.

\section{Plant height (cm)}

Mean square data showed highly significant $(p \leq 0.01)$ differences among plant height of the tomato genotypes (Table 2). It varied between 49.9 to $102.6 \mathrm{~cm}$. Minimum plant height $(49.9 \mathrm{~cm})$ was observed for tomato genotype Roma. Tomato genotype 017875 manifested maximum plant height (102.6 $\mathrm{cm}$ ) followed by 00289,006234 and 006231 with values of $92.1,89.6$ and $87.4 \mathrm{~cm}$, respectively (Table 6). The findings of this study are in line with the results of [18] who reported highly significant differences for plant height in their study. High PCV $(22.93 \%)$, GCV (21.72\%), and heritability $(89.7 \%)$ values were observed among the tomato genotypes for plant height (Table 4). The findings of [22] are in agreement with our results and reported high PCV $(21.72 \%)$ and heritability $(70.8 \%)$ while moderate GCV $(18.27 \%)$ for this trait.

Table 5. Mean values for number of primary branches plant ${ }^{-1}$, number of secondary branches plant $^{-1}$, fruit length and fruit diameter of different tomato genotypes

\begin{tabular}{|c|c|c|c|c|}
\hline Genotypes & $\begin{array}{c}\text { Number of primary } \\
\text { branches plant }^{-\mathbf{1}}\end{array}$ & $\begin{array}{c}\text { Number of secondary } \\
\text { branches plant }^{-1}\end{array}$ & $\begin{array}{c}\text { Fruit length } \\
\text { (cm) }\end{array}$ & $\begin{array}{c}\text { Fruit diameter } \\
\text { (cm) }\end{array}$ \\
\hline Red wonder & 7.0 & 13.0 & 5.18 & 4.77 \\
\hline Bombino & 7.0 & 10.0 & 5.84 & 4.99 \\
\hline Riogrande & 7.0 & 13.0 & 4.85 & 4.63 \\
\hline Roma & 6.0 & 8.0 & 5.24 & 4.46 \\
\hline Rio figou & 6.0 & 14.0 & 3.93 & 3.81 \\
\hline Jumbo & 8.0 & 16.0 & 4.83 & 4.22 \\
\hline Kalam & 6.0 & 15.0 & 4.93 & 4.26 \\
\hline NSF-VF & 8.0 & 10.0 & 4.87 & 4.47 \\
\hline Red star & 7.0 & 12.0 & 4.91 & 4.64 \\
\hline 006234 & 8.0 & 20.0 & 3.23 & 3.33 \\
\hline 006231 & 8.0 & 23.0 & 3.47 & 3.65 \\
\hline 00289 & 10.0 & 20.0 & 3.40 & 3.58 \\
\hline 006232 & 10.0 & 16.0 & 3.49 & 3.82 \\
\hline 017875 & 10.0 & 24.0 & 3.35 & 3.79 \\
\hline 017872 & 10.0 & 19.0 & 4.03 & 3.85 \\
\hline
\end{tabular}

\section{Fruit yield (kg plot $\left.{ }^{-1}\right)$}

Tomato fruit yield is an important parameter and plant breeders are interested in evolving new genotypes having high fruit yield. Mean square data showed highly significant $(\mathrm{p} \leq$ 0.01) differences among the tomato genotypes for fruit yield plot $^{-1}$ (Table 2). Mean values for fruit yield, among the tomato genotypes, ranged from 1.08 to 3.74 $\mathrm{kg}$ (Table 6). Tomato genotype 00289 produced minimum fruit yield $\left(1.08 \mathrm{~kg} \mathrm{plot}^{-}\right.$ $\left.{ }^{1}\right)$. Maximum fruit yield $\left(3.74 \mathrm{~kg} \mathrm{plot}^{-1}\right)$ was observed for tomato genotype Red Wonder followed by Bombino, Red Star and Roma with values of $2.83,2.52$ and $2.46 \mathrm{~kg}$ plot $^{-1}$ (Table 6). [22] Manifested similar results and showed highly significant differences among the tomato genotypes for fruit yield plot $^{-1}$. In this study, high PCV (42.92\%), GCV $(39.63 \%)$ and heritability $(85.2 \%)$ values were recorded among the tomato genotypes for fruit yield plot $^{-1}$ (Table 4). Findings of [12] are in accordance with our results. They also reported high PCV (40.80\%), GCV 
(29.67\%) and heritability $(97.97 \%)$ for fruit yield plot $^{-1}$.

Table 6. Mean values for number of fruit clusters plant ${ }^{-1}$, plant height and fruit yield plot $^{-1}$ of different tomato genotypes

\begin{tabular}{|c|c|c|c|}
\hline Genotypes & Number of fruit clusters plant ${ }^{-1}$ & Plant height (cm) & Fruit yield (kg plot $\left.{ }^{-1}\right)$ \\
\hline Red wonder & 14.0 & 59.4 & 3.74 \\
\hline Bombino & 16.0 & 60.9 & 2.83 \\
\hline Riogrande & 19.0 & 65.1 & 1.89 \\
\hline Roma & 14.0 & 49.9 & 2.46 \\
\hline Rio figou & 23.0 & 71.8 & 1.61 \\
\hline Jumbo & 22.0 & 71.6 & 1.17 \\
\hline Kalam & 27.0 & 76.8 & 1.10 \\
\hline NSF-VF & 12.0 & 57.3 & 2.33 \\
\hline Red star & 14.0 & 50.3 & 2.52 \\
\hline 006234 & 25.0 & 89.6 & 1.33 \\
\hline 006231 & 27.0 & 87.4 & 1.29 \\
\hline 00289 & 28.0 & 92.1 & 1.08 \\
\hline 006232 & 24.0 & 85.7 & 1.83 \\
\hline 017875 & 24.0 & 102.6 & 1.61 \\
\hline 017872 & 23.0 & 85.2 & 1.33 \\
\hline
\end{tabular}

\section{Conclusion}

In the present study, tomato genotypes showed highly significant differences for all the studied parameters except days to first flower initiation. Tomato genotype 006231 displayed maximum number of flowers cluster $^{-1}$ and fruits infloresecence ${ }^{-1}$. Maximum number of primary branches plant 1 and secondary branches plant ${ }^{-1}$ were observed for genotype 017875. Maximum fruit length and fruit diameter were recorded for Bambino. Highest plants and maximum fruit clusters plant $^{-1}$ were manifested by tomato genotypes 017875 and 00289 , respectively. Genotype Red Wonder produced maximum fruit yield plot $^{-1}$. Higher values of phenotypic coefficient of variation (PCV) and genotypic coefficient of variation (GCV) were observed for number of secondary branches plant ${ }^{-1}$, number of fruit clusters plant $^{-1}$, plant height and fruit yield plot $^{-1}$. High broad sense heritability values were obtained for number of secondary branches plant ${ }^{-1}$, fruit diameter, number of fruit clusters plant $^{-1}$, plant height and fruit yield plot $^{-1}$. The tomato genotypes Red Wonder, Bombino, 006231, 00289 and 017875 performed better for yield and yield related traits in the local climatic conditions of District Swabi. These genotypes could be used in future tomato breeding programs to develop segregating generations for the identification of best tomato variety/hybrid.

\section{Authors' contributions}

Conceived and designed the experiments: $\mathrm{M}$ Ismaeel, Performed the experiments: $\mathrm{M}$ Saleem Khan \& M Naeem, Analyzed the data: M Ismaeel \& $M$ Saleem Khan, Contributed materials/ analysis/ tools: Z Ali, A Ali \& S Tawab, Wrote the paper: M Saleem Khan \& M Ismaeel.

\section{References}

1. Anonymous (2005). FAOSTAT database. Food and Agriculture Organization of the United Nation, Rome, Italy. http://www.faostat.fao.org.

2. Takeoka GR, Dao L, Flessa S, Gillespie DM, Jewell WT \& Huebner B (2001). Processing effects on lycopene content and antioxidant activity of tomatoes. J Agri Food Chem 49: 3713-3717. 
3. MNFSR (2014). Agriculture Statistics. Ministry of National Food Security and Research, Islamabad. Available from http://www. mnfsr.gov.pk (accessed on 05 ${ }^{\text {th }}$, July, 2018).

4. Shokat S, Azhar FM, Iqbal Q, Nabi G, Raza MM \& Sallem M (2013). Heritability studies of fruit related traits in Solanum lycopersicum L. germplasm. J. Bio Life Sci 4(2): 56-62.

5. Stevens MA \& Rick M (1986). The tomato crop a scientific basis for improvement. In Atherton, J G \& Rudich. (eds). Genetics and breeding, Chapman and Hall, London. 35109.

6. Baisden G (1994). Frankenfood bioengineered bonanza of the future or your worst night more come true. The growing edge 5(4): 34-42.

7. Sunday OF, Ayodele AM, Babatunde KO \& Oluwole AM (2007). Genotypic and phenotypic variability for seed vigor traits and seed yield in west African rice genotypes. J Ameri Sci 3(3): 35-41.

8. Falconner DS \& Mackay TFC (1996). Introduction to quantitative genetics $4^{\text {th }} \mathrm{Ed}$. Benjammin Cummings England. 464.

9. Steel RGD \& Torrie JH (1980). Principles and procedure of statistics, $2^{\text {nd }} \mathrm{Ed}$ New York: McGraw-Hill.

10. Singh RK \& Chaudhary BD (1985). In: Biometrical methods in quantitative genetics analysis. Kalyani publishers, Ludhiana, India.

11. Kanneh SM, Queen DD, Nagegba PM \& Musa PD (2017). Evaluation of tomato genotypes for horticultural characteristics on the upland in Sierra Leone. J Agri Sci 9 (6): 213.

12. Ali W, Jilani MS, Naeem N, Wassem K, Khan J, Ahmad MJ \& Ghazanfarullah (2012). Evaluation of different hybrids of tomato under the climatic conditions of Peshawar. Sarh J Agric 28 (2): 207-212.

13. Kherwa RS, Solankey SS, Akhtar S, Kumar A \& Kumari R (2018). Genetic study of wild and cultivated tomato (Solanum lycopersicum Mill.) genotypes. Int J Curr Micribiol App Sci 7: 2568-2574.
14. Sureshkumara B, Lingaiah HB, Shivapriya M \& Pavithra HB (2017). Evaluation of tomato genotypes for growth, yield and quality attributes under eastern dry zone of Karnataka, India. Int J Curr Microbiol App Sci 6(11): 1922-1930.

15. Meena ML, Singh V, Meena DC \& Meena JK (2017). Evaluation and variability of some genotypes of tomato (Lycopersicon esculentum Mill) for horticultural traits. Int J Pure App Bio Sci 5 (4): 586-591.

16. Charnet S, Belew D \& Abay F (2014). Genetic diversity studies for quantitative traits of tomato (Solanum lycopersicm L.) genotypes in Western Tigray, Northern Ethiopia. J P B crop Sci 6 (9): 105 -113.

17. Hasan MM, Bari MAA \& Hossain MA (2016). Genetic variability and traits association analysis of tomato (Lycopersicon esculentum L.) genotypes for yield and quality attributes. Uni J Pl Sci 4(3): 23-34.

18. Parajapati S, Tiwari A, Kadwey S \& Jamkar T (2015). Genetic variability, Haritability \& Genetic advance in tomato (Solanum lycopersicum L.) Int J Agri Env \& Biotech 8(2) 245-251.

19. Henareh M, Dursun A \& Mandoulakani BA (2015). Genetic diversity in tomato landraces collected from Turkey and Iran revealed by morphological characters. Acta Sci Pol Hortorum Cultus 14(2): 87-96.

20. Ullah MZ, Hassan L, Shahid SB \& Patwary AK (2015). Variability and inter relationship studies in tomato (Solanum lycopersicum L.). J Bang Agri Uni 13(1): 65-69.

21. Golani IJ, Mehta DR, Purohit VL, Pandya HM \& Kanzariya MV (2007). Genetic variability, correlation and path coefficient studies in tomato. Ind J Agric Res 41(2): 146-149.

22. Spaldon S \& Hussain S (2017). Performance of tomato (Solanum lycopersicum L.) genotypes for yield and quality traits under Jummu subtropical condition. Inter J Agric Inno Res 6(1): 1473-2319. 